\title{
MANAJEMEN KOMUNIKASI PELAKSANAAN \\ OPERASI AMAN NUSA II MADAGO RAYA 2021 POLRES SIGI DALAM PERCEPATAN DAN ANTISIPASI WABAH COVID-19
}

\author{
Israwaty Suriady $^{1 *}$, Fitriani Puspa Ningsih ${ }^{1}$, Nurhaidar ${ }^{1}$ \\ ${ }^{1}$ Program Studi Ilmu Komunikasi FISIP Universitas Tadulako \\ *Email: israwaty@untad.ac.id
}

\begin{abstract}
This article is based on the spread of the Covid-19 outbreak in Indonesia, including in the Central Sulawesi Province. In response to this, the government took various steps to handle and prevent the outbreak, one of which was implemented through the establishment of the Task Force for the Acceleration of Handling the Covid-19 Outbreak at the District and District Levels. In the Sigi Regency area, this task force works under the auspices of the Safe Operations Task Force Nusa II Madago Raya. Involving elements of the Police, TNI, and other related elements, this operation program has carried out various activities in an effort to deal with Covid-19 in the Sigi Regency area. Using qualitative methods, this study aims to see how the communication management of the Aman Nusa Madago Raya II operation of the Sigi Police Station is. The results of the study found four important stages in communication management which were described quite well in the implementation of the program.
\end{abstract}

Keywords: Communication Management; Covid-19; Aman Nusa

\begin{abstract}
ABSTRAK
Artikel ini didasari oleh meluasnya wabah Covid-19 di Indonesia termasuk di wilayah Provinsi Sulawesi Tengah. Menyikapi hal itu, pemerintah mengambil berbagai langkah guna penanganan dan pencegahan wabah salah satunya diimplementasikan melalui pembentukan Gugus Tugas Percepatan Penanganan Wabah Covid-19 Tingkat Kabupaten dan Kecamatan. Di wilayah Kabupaten sigi gugus tugas ini bekerja dalam naungan Satuan Tugas (satgas) Operasi Aman Nusa II Madago Raya. Melibatan unsur Polri, TNI, serta unsur terkait lainnya program operasi ini telah melakukan berbagai kegiatan dalam upaya penanganan Covid $! 9$ di wilayah Kabupaten Sigi. Menggunakan metode kualitatif, penelitian ini bertujuan untuk melihat bagaimana manajemen komunikasi dari operasi Aman Nusa Madago Raya II Polres Sigi ini. Hasil penelitian menemukan empat tahapan penting dalam menajemen komunikasi yang dijabarkan cukup baik dalam implementasi programnya.
\end{abstract}

Kata Kunci: Manajemen Komunikasi; Covid-19; Aman Nusa

Submisi: 9 November 2021

\section{Pendahuluan}

Covid-19 masih menjadi masalah kesehatan dunia. Kasus ini di awali dengan informasi dari Badan Kesehatan Dunia/World Health Organization (WHO) pada tanggal 31 Desember 2019 yang menyebut kan adanya kasus kluster pneumonia denganetiologi yang tidak jelas di Kota Wuhan, Provinsi Hubei, Cina. Kasus ini terus berkembang hingga adanya laporan kematian dan terjadi importasi di luar Cina. Pada tanggal 30 Januari 2020, WHO menetapkan Covid-19 sebagai Public Health Emergency of International Concern (PHEIC)/Kedaruratan Kesehatan Masyarakat yang Meresahkan Dunia (KKMMD). Pada tanggal 12 Februari 2020, WHO resmi menetapkan penyakit virus Corona pada manusia ini dengan sebutan Corona virus Disease (Covid-19). Pada 
tanggal 2 Maret 2020 Indonesia telah melaporkan dua kasus konfirmasi Covid-19. Pada tanggal 11 Maret 2020, WHO sudah menetapkan Covid-19 sebagai pandemic (World Health Organization, 2020).

Sepanjang 2020 angka konfirmasi dari kasus covid 19 di Indonesia kian meningkat, bahkan hingga di tahun 2021. Pemerintah telah melakukan berbagai upaya guna menekan laju penyebaran virus ini. Seluruh pihak dipastikan berperan dalam penanganannya dan saling bersinergi serta berkontribusi, tak terkecuali jajaran Kepolisian Republik Indonesia (Polri). Di wilayah kerja kepolisian Daerah Sulawesi Tengah menerjemahkan instruksi pemerintah pusat melalui satgas Aman Nusa Madago Raya II untuk penanganan Covid 19 dalam rangka percepatan antisipasi dampak Covid-19. Tupoksi utama dalam Operasi Aman Nusa Madago Raya II diantaranya memberikan pemahaman kepada masyarakat luas terkait bagaimana memperkecil penyebaran virus ini melalui berbagai langkah antisipatif.

Di wilayah Kabupaten Sigi, langkahlangkah penanganan yang dilakukan pemerintah dalam hal ini Polri adalah hal mendesak yang harus digiatkan. Mengingat kedisiplinan penerapan protokol kesehatan di wilayah tersebut masih rendah.

Penelitian ini mencoba mendeskripsikan bagaimana Kepolisian wilayah Resort Sigi (Polres Sigi) menjalankan manajemen komunikasi dalam operasi aman nusa II Madago Raya ini. Manajemen komunikasi menyiratkan penggunaan sumber daya manusia dan teknologi secara optimal untuk menjalin hubungan antarmanusia. Hakikatnya mengusulkan agar individu dapat mengoptimalkan sumber dayanya ke dalam aspek pengelolaan manajemen di organisasi dengan menggunakan model komunikasi yang sistimatis sehingga memudahkan aktivitas komunikasi manajemen di seluruh unit organisasi.

Dalam cakupan konsep, penelitian ini mengkhususkan pada implementasi manajemen komunikasi dalam pelaksanaan operasi aman nusa madago raya II di Kabupaten Sigi. Mengacu pada konsep yang dikemukakan oleh Robert E. Simmons, dijelaskan melalui empat (4) tahapan yang disebut managerial planning, yakni Reorganize large masses of information into simpler yet more meaningful categories. Dimana tahap ini bertujuan memudahkan para anggota organisasi dalam memahami dan melaksanakan pekerjaan yang sesuai dengan kebijakan dan arahan pimpinan. Differentiate important information and eliminate non essential information. Tahap ini bertujuan memilih-milih sedemikian rupa informasi mengenai pekerjaan agar pelaksana pekerjaan dapat membuat prioritas pekerjaan berdasarkan tingkatan informasinya. View problem-connected events, phenomena and concepts in an integrated context that makes it easier to make sense of, or explain what is occurring. Tahapan ini diperlukan sebagai upaya untuk membuat spesifikasi pekerjaan dan mendistribusikannya kepada bawahan/karyawan, sesuai dengan wewenang dan tanggung jawabnya, serta mampu mengantisipasi kemungkinan yang terjadi. Tahapan terakhir yaitu Formulate strategy that can serve as the basic for plans and their implementations. Merupakan tahapan yang sangat menentukan keberhasilan organisasi/perusahaan dalam mencapai tujuan.rumusan strategi yang tepat dan mudah diimplementasikan akan menciptakan suasana kerja yang kondusif dan mendorong terciptanya kinerja yang memuaskan karyawan dan organisasi/perusahaan. Keempat tahapan tersebut merupakan dasar untuk berkembang dan berubahnya suatu organisasi/perusahaan.

Terdapat sejumlah penelitian terdahulu yang relevan dengan penelitian ini, diantaranya penelitian yang dilakukan oleh Muhammad Arif dan Suci Sinta Lestari (2021, jurnal Komunikasiana: Journal of Communication Studies) dengan judul Manajemen Komunikasi Bencana Pemerintah Desa dalam Penanganan Covid19. Penelitian tersebut berangkat dari 
kompleksitas permasalahan bencana Covid19 yang diyakini memerlukan suatu penataan atau manajemen komunikasi yang matang dalam upaya penanganannya yang terarah dan terpadu. Menggunakan metode deskriptif kualitatif, penelitian tersebut bertujuan untuk menjelaskan bagaimana manajemen komunikasi bencana yang dilakukan oleh pemerintah desa dalam penanganan Covid-19. Sampel ditentukan dengan menggunakan purposive sampling, sedangkan teknik pengambilan data menggunakan teknik wawancara mendalam (indepth interview) dan observasi. Hasil dari penelitian tersebut menunjukkan pentingnya koordinasi dan komunikasi antar pihak terkait manajemen komunikasi bencana. Melalui pendekatan model alternatif manajemen komunikasi bencana meliputi aspek perencanaan, pengorganisasian, pelaksanaan dan evaluasi. Hubungan baik antara pemerintah desa dan warga masyarakat, dapat menciptakan manajemen komunikasi bencana yang efektif sehingga resiko bencana yang mungkin muncul dapat dikurangi bahkan dihindari.

Relevansi penelitian ini dengan penelitian yang disebutkan diantaranya datang dari permasalahan yang sama yakni bagaimana penanganan covid-19 dalam masyarakat ditinjau dari aspek manajemen komunikasi yang melekat pada tugas dan pokok fungsi organisasi yang terlibat didalamnya. Bagaimana optimalisasi peran yang dilakukan pemerintah selaku fasilitator sekaligus pengayom bagi masyarakat.

\section{Manajemen Komunikasi}

Manajemen komunikasi oleh Harry Irwan, didefinisikan sebagai The process of using human, financial and technical resources in understanding and performing the communications function within corporation and between those and theirs publics (proses yang menggunakan manusia, keuangan dan sumber teknik yang berfungsi membentuk komunikasi antarperusahaan dan antara perusahaan dengan publiknya). Sedangkan Michael Kaye memberikan pengertian, Communications management, implies the optimal use of human and trchnological resources to promote dialogue between people. (Manajemen komunikasi menyiratkan penggunaan sumber daya manusia dan teknologi secara optimal untuk menjalin hubungan antarmanusia). Kedua pengertian manajemen komunikasi tersebut pada hakikatnya mengusulkan agar individu dapat mengoptimalkan sumber dayanya kedalam aspek pengelolaan manajemen di organisasi atau perusahaan dengan menggunakan model komunikasi yang sistimatis sehingga memudahkan aktivitas komunikasi manajemen di seluruh unit organisasi/perusahaan.

Selanjutnya, Egan dan Cowan menegaskan bahwa model tersebut harus konsisten terhadap dua hal, yaitu: Pertama, model merupakan alat mengukur kekuatan dan kelemahan dari human system dan, kedua, model dipusatkan pada management strategic dari human system (Human system is networks of communicsting people that range from units as small as nuclear families to large organizations, communicaties and neighbourhoods). Human system adalah jaringan kerja dari komunikasi antarmanusia yang bentuknya terbentang dari unit-unit terkecil sebagai kekuatan keluarga ke organisasi yang besar, komunitas dan lingkungan. Dari uraian tersebut, proses manajemen komunikasi dapat dipahami sebagai sebuah proses koordinasi interpretasi atau pengertian yang dibangun melalui interaksi antar manusia.

Kemampuan

berkomunikasi

dilakukan dengan saling memahami pandangan dan kerangka berpikir masingmasing dalam lingkungan yang beragam.Berkaitan dengan pengelolaan perusahaan/organisasi, Irwin menambahkan bahwa kegiatan manajemen komunikasi dan kegiatan dicorporate communications tidak dapat dipisahkan.Keduanya merupakan aplikasi dari fungsi-fungsi manajemen. Sejalan dengan konsep umum manajemen as the process og getting done through and with people dan komunikasi as a process of 
interrelated elements working together to achieve a desired outcome or goal, manajemen komunikasi dipahami sebagai proses yang sistematis antara anggota organisasi/perusahaan dalam menjalankan fungsi-fungsi manajemen untuk menyelesaikan pekerjaan melalui proses negoisasi pengertian/pemahaman antara satu individu maupun lebih yang bertujuan mencapai keinginan dan kepuasan bersama.

Manajemen komunikasi sangat identik dengan interaksi sosial. Ada kalanya kita harus mampu untuk memposisikan diri dengan tepat dalam situasi tertentu, kita juga harus mampu menghadapi dan menjalin kerjasama dengan orang lain tanpa mencampurnya dengan urusan pribadi. Ini merupakan sebagian alasan diperlukannya sikap professional dalam diri anda masingmasing. Manajemen komunikasi berada di dalam dan diantara sistem sosial. Manajemen komunikasi meliputi P4I (Penerimaan, Pengolahan, Penyimpanan, dan Penyampaian Informasi) dalam sub-sub sistem soaial, diantaranya adalah individu, kelompok, organisasi, massa, dan masyarakat.

Konsep manajemen dalam perspektif ilmu komunikasi pada hakikatnya dipahami sebagai proses memengaruhi orang lain. Selain itu, konsep dari manajemen komunikasi juga memberi saran kepada kita bahwa kemampuan untuk berkomunikasi dengan baik bukan hanya sebagai hal yang sudah melekat dalam diri kita saja, melainkan sebagai suatu hal yang dapat kita pelajari dan kita kembangkan. Sebagai contohnya, kita dapat meningkatkan kemampuan kita dalam berkomunikasi agar dapat menjadi seorang komunikator yang memiliki kredibilitas. Disinilah letak kegunaan mempelajari manajemen komunikasi, yaitu agar kita dapat lebih mengerti bagaimana seharusnya berkomunikasi dengan orang lain, sehingga komunikasi yang terjadi merupakan komunikasi yang efektif. Komunikasi dalam manajemen diibaratkan sebagai "minyak pelumas" bahkan GR. Terry mengatakan bahwa management is communications.
Dari pendapat tersebut terlihat betapa pentingnya peran komunikasi dalam kegiatan manajemen.

GR. Terry mengemukakan bahwa dalam suatu kegiatan manajemen terdapat lima bentuk komunikasi, antara lain:

a. Komunikasi formal. Biasanya terjadi dalam jalus komunikasi formal, memiliki wewenang dan tanggung jawab yaitu melalui instruksiinstruksi bentuk lisan dan tulisan sesuai dengan prosedur secara fungsional yang berlaku dari arus atasan ke bawahan atau sebaliknya.

b. Komunikasi non-formal, yaitu di luar komunikasi formal, terjadi secara spontan. Misalnya Sumbang saran yang berkaitan dengan tugas, kewajiban. Efektif digunakan dalam perusahaan yang bersifat padat karya dengan jumlah pekerja cukup banyak, dan tidak terlalu teknis.

c. Komunikasi informal. Seperti halnya komunikasi non formal namun lebih menekankan pada aspek human relations-nya. Atau dengan kata lain digunakan dalam permasalahan di luar pekerjaan secara langsung.

d. Komunikasi teknis. Biasanya hanya dilakukan dan dimengerti oleh orang-orang tertentu saja yang berkaitan dengan kegiatan tersebut.

e. Komunikasi prosedural. Biasanya dekat dengan komunikasi formal, diwujudkan misalnya dalam bentuk pemberian laporan tahuan/bulanan, instruksi tertulis, memo dan lainlain.

Empat alasan yang dapat dikemukakan sebagai landasan signifikansi bagi pengembangan subdisiplin ilmu manajemen komunikasi di dalam situasi globalisasi dewasa ini. Alasan tersebut adalah :

a. Terkait dengan tujuan ilmu komunikasi, Menurut Soesanto (1976), komunikasi bertujuan untuk menciptakan keharmonisan diantara pelaku-pelaku komunikasi. Pola tindakan komunikasi untuk 
mencapai itu semua bukan hanya reaktif semata-mata, tetapi juga harus penuh dengan strategi. Manajemen komunikasi yang menggabungkan antara pendekatan manajemen dengan pengelolaan komunikasi memungkinkan kita untuk mewujudkan keharmonisan dalam komunikasi yang kita lakukan.

b. Didasarkan pada karakteristik ilmu komunikasi. Karakteristik ilmu komunikasi antara lain bersifat irreversible, kompleks, berdimensi sebab akibat, dan mengandung potensi problem. Dilihat dari karakteristik tersebut suatu proses komunikasi sangatlah rumit. Maka suatu tindakan komunikasi haruslah dikelola secara tepat. Disinilah subdisiplin manajemen komunikasi dapat memberikan kontribusinya.

c. Terkait dengan kebutuhan fungsionalisasi ilmu komunikasi didalam upaya menciptakan/ knowledge worker di bidang komunikasi. Knowledge worker adalah tenaga komunikasi yang memiliki wawasan teoritis tentang komunikasi dan memiliki keterampilan dalam mengaplikasikan ilmu tersebut. Dalam studi manajemen komunikasi, suatu model pembelajaran komunikasi yang mengarah pada pembekalan meaningful knowledge dan meaningful skills dapat dikonstruksi.

d. Adanya asumsi peran ilmu manajemen akan semakin dominan dalam abad XXI sementara peran ilmu komunikasi akan semakin dibutuhkan dalam era globalisasi. Berdasarkan asumsi tersebut, maka kedua disiplin ilmu ini bersinergi dalam memecahkan berbagai persoalan sosial-komunikasi di masa sekarang dan akan datang.

Komunikasi dipandang sebagai sentral elemen-elemen lainnya dalam kegiatan manajemen organisasi. Alasan pertama, komunikasi memiliki fungsi untuk mempertemukan antara tujuan organisasi dengan terget hasil yang dicapai. Kedua, berfungsi untuk mengadaptasikan perubahan lingkungan organisasi. Ketiga, untuk membina hubungan antar anggota organisasi dalam melaksanakan berbagai tugas (beban kerja) organisasi.

\section{Implementasi Manajemen Komunikasi}

Implementasi manajemen

komunikasi ke dalam sistem kegiatan di organisasi/perusahaan oleh Robert E. Simmons, dijelaskan melalui empat (4) tahapan yang disebut managerial planning, yaitu:

a. Reorganize large masses of information into simpler yet more meaningful categories.

Tahap ini bertujuan memudahkan para anggota organisasi/perusahaan dalam memahami dan melaksanakan pekerjaan yang sesuai dengan kebijakan dan arahan pimpinan.

b. Differentiate important information and eliminate non essential information.

Tahap ini bertujuan memilih-milih sedemikian rupa informasi mengenai pekerjaan agar pelaksana pekerjaan dapat membuat prioritas pekerjaan berdasarkan tingkatan informasinya.

c. View problem-connected events, phenomena and concepts in an integrated context that makes it easier to make sense of, or explain what is occurring.

Manajer membutuhkan tahapan ini sebagai upaya untuk membuat spesifikasi pekerjaan dan mendistribusikannya kepada karyawan, sesuai dengan wewenang dan tanggung jawabnya, serta mampu mengantisipasi kemungkinan yang terjadi.

d. Formulate strategy that can serve as the basic for plans and their implementations. Merupakan tahapan yang sangat menentukan keberhasilan organisasi/perusahaan dalam mencapai tujuan.rumusan strategi yang tepat dan mudah diimplementasikan akan 


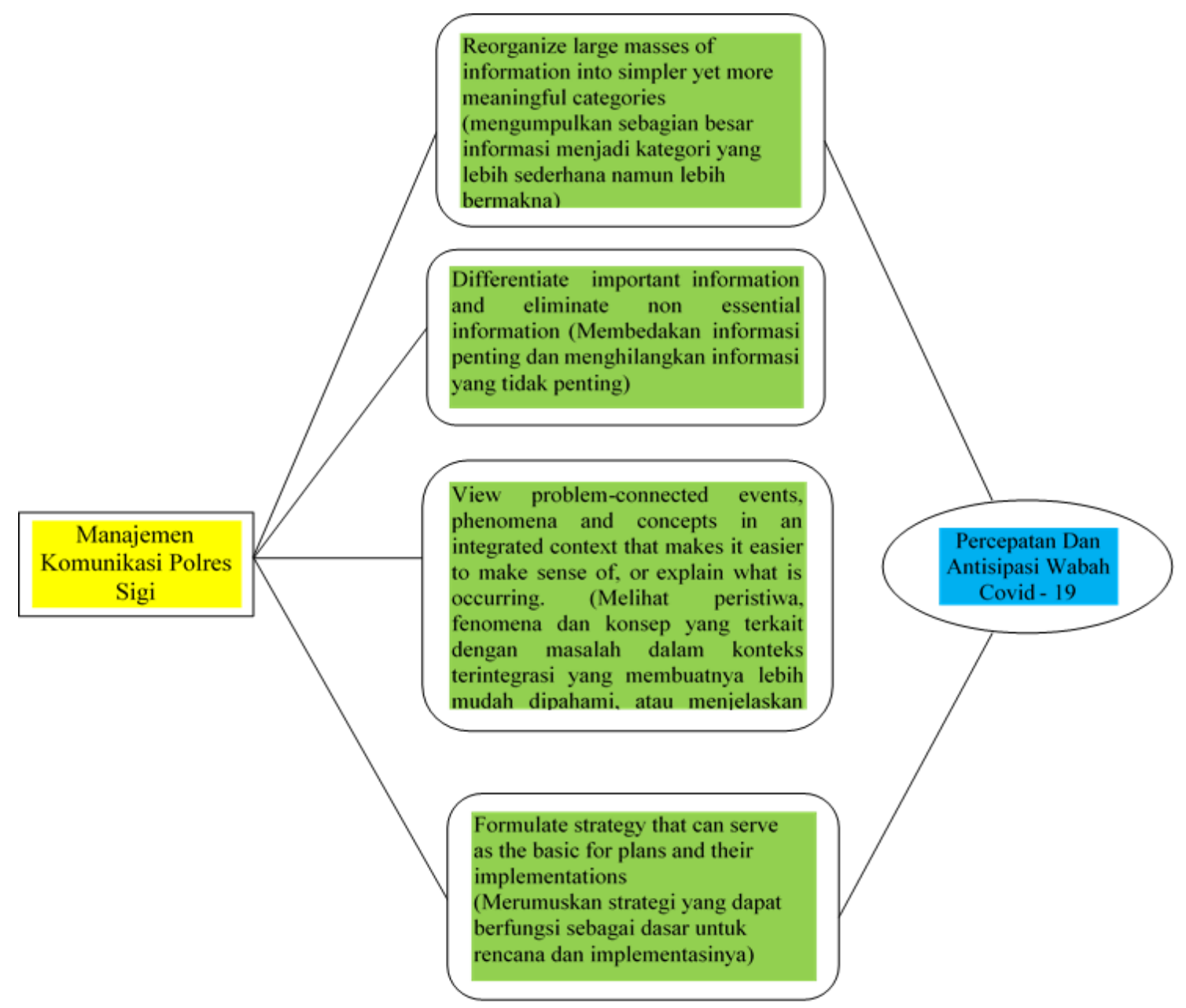

Gambar 1. Skema Kerangka Pikir

menciptakan suasana kerja yang kondusif dan mendorong terciptanya kinerja yang memuaskan karyawan dan organisasi/perusahaan.
Keempat
tahapan
tersebut merupakan dasar untuk berkembang dan berubahnya suatu organisasi/perusahaan. Tahapan tersebut akan efektif bila dilakukan dengan melibatkan seluruh unsur yang terkait dalam aktivitas pengelolaan organisasi/perusahaan dan menjalankan secara sistematis fungsi-fungsi utama dalam manajemen menurut G.R Terry, yaitu:

\section{a. Perencanaan (Planning)}

Yaitu sebagai dasar pemikiran dari tujuan dan penyusunan langkah -langkah yang akan dipakai untuk mencapai tujuan. Merencanakan berarti mempersiapkan segala kebutuhan, memperhitungkan matang-matang apa saja yang menjadi kendala, dan merumuskan bentuk pelaksanaan kegiatan yang bermaksud untuk mencapai tujuan.

$\begin{array}{crr}\text { b. Pengorganisasian (Organizing) } & \\ \text { Yaitu sebagai cara untuk } & \text { ua } \\ \text { mengumpulkan } & \text { orang-orang } & \text { dan }\end{array}$ menempatkan mereka menurut kemampuan dan keahliannya dalam pekerjaan yang sudah direncanakan.

\section{c. Penggerakan (Actualing)}

Yaitu untuk menggerakan organisasi agar berjalan sesuai dengan pembagian kerja masing-masing serta menggerakan seluruh sumber daya yang ada dalam organisasi agar pekerjaan atau kegiatan yang dilakukan bisa berjalan sesuai rencana dan bisa mencapai tujuan. 
d. Pengawasan (Controlling)

Yaitu untuk mengawasi apakah gerakan dari organisasi ini sudah sesuai dengan rencana atau belum.Serta mengawasi penggunaan sumber daya dalam organisasi agar bisa terpakai secara efektif dan efisien tanpa ada yang melenceng dari rencana.

\section{Konseptualisasi Penelitian}

Menurut Creswell (2016) penelitian kualitatif adalah jenis penelitian yang mengeksplorasi dan memahami makna di sejumlah individu atau sekelompok orang yang berasal dari masalah sosial. Penelitian kualitatif secara umum dapat digunakan untuk penelitian tentang kehidupan masyarakat, sejarah, tingkah laku, konsep atau fenomena, masalah sosial, dan lain-lain. Jenis penelitian kualitatif yang digunakan oleh peneliti dalam penelitian ini adalah studi kasus. Studi kasus merupakan studi yang mengeksplorasi suatu kasus secara mendalam, mengumpulkan informasi secara lengkap dengan menggunakan berbagai prosedur pengumpulan data berdasarkan waktu yang telah ditentukan. Tipe penelitian pada prinsipnya merupakan pengkasifikasian penelitian berdasarkan atas tujuan penjelasan atau tingkat penjelasan terhadap variabel penelitian yang ingin dicapai oleh peneliti. Tipe penelitian berkaitan dengan analaisis data. Penelitian ini menggunakan metode deskriptif. Dimana penelitian deskriptif hanyalah memaparkan situasi atau peristiwa. Penelitian ini tidak mencari atau menjelaskan hubungan, tidak menguji hipotesis atau membuat prediksi. Pada hakikatnya, metode deskriptif mengumpulkan data secara univariat.

Informan dalam penelitian ini berjumlah dua orang yang diambil dengan metode purposive sampling yakni pengambilan sampel dengan tujuan tertentu. Adapun sampel yang diambil dalam hal ini informan berjumlah empat orang yakni mereka yang ditentukan dengan sejumlah kriteria diantaranya adalah mereka yang terlibat langsung dan memiliki peran penting dalam struktur satgas operasi aman nusa madago raya II Polres Kabupaten Sigi. Hasil penelitian ini diperoleh dari data primer dan sekunder. Data primer diperoleh dari hasil wawancara mendalam dengan informan terkait, sedangkan data sekunder merujuk pada sejumlah data lain yang telah diolah dari berbagai sumber referensi dan dokumen. Data dianalisis berdasarkan tiga tahapan analisis data yakni reduksi data, penyajian data dan penarikan kesimpulan.

\section{Hasil Penelitian}

\section{Manajemen Komunikasi Pelaksanaan Operasi Aman Nusa Madago Raya 2021 Polres Sigi Dalam Percepatan Dan Antisipasi Wabah Covid - 19}

Menyikapi perkembangan wabah Covid-19 di wilayah Kab. Sigi, penanganan dan pencegahan wabah Covid melalui Maklumat Kapolri, Surat Edaran Bupati Sigi, himbauan social distancing, phisical distancing, stay at home, pola hidup bersih, dalam rangka pencegahan wabah covid sudah dilaksanakan setiap harinya siang dan malam hari, baik secara sendiri-sendiri oleh masing-masing instansi maupun secara sinergi bersama Polri dan TNI.

Melalui Gugus Tugas Percepatan Penanganan Wabah Covid19 Tingkat Kabupaten dan Kecamatan, Satgas Ops Aman Nusa II 2020, dan operasi-operasi kepolisian selama tahun 2020, pada lokasilokasi publik seperti pasar-pasar, tempat wisata, jalan-jalan poros, baik melalui penyebaran stiker, selebaran, pamflet, dan pengeras suara. Secara umum himbauan himbauan tersebut dapat diterima oleh masyarakat dan tidak memunculkan sikap resitensi, namun masyarakat masih sulit untuk melaksanakannya terutama untuk menghindari kerumunan massa.

Satgas Aman Nusa Madago Raya II dilaksanakan untuk penanganan Covid -19 dalam rangka percepatan antisipasi dampak Covid-19. Personel yang terlibat dalam Operasi Aman Nusa Madago Raya II dapat memberikan pemahaman kepada 
masyarakat luas untuk tidak melakukan kegiatan-kegiatan yang sifatnya berkumpul secara beramai-ramai atau menghindari tempat keramaian seperti yang telah dianjurkan pihak pemerintah.

Pentingnya berdisiplin dalam menerapkan protokol kesehatan. Sebab, masyarakat yang lengah rentan terjangkit virus corona. angka kasus positif Covid-19 akan selalu naik jika masyarakat tidak waspada dalam mencegah penularan virus corona. Misalnya dengan selalu menggunakan masker di ruang publik, menjaga jarak fisik dan rajin mencuci tangan dengan sabun.

Reorganize large masses of information into simpler yet more meaningful categories (mengumpulkan sebagian besar informasi menjadi kategori yang lebih sederhana namun lebih bermakna)

Pada Tahap ini bertujuan memudahkan para anggota dalam memahami dan melaksanakan pekerjaan yang sesuai dengan kebijakan dan arahan pimpinan. Tahap ini merupakan tahap dimana sebuah instansi terkhusus polres sigi membuat perencanaan strategi yang akan ditetapkan untuk membuat kebijakan dan arahan yang akan dijalankan oleh anggota.

Manajemen komunikasi sangat identik dengan interaksi sosial. Ada kalanya kita harus mampu untuk memposisikan diri dengan tepat dalam situasi tertentu, kita juga harus mampu menghadapi dan menjalin kerjasama dengan orang lain tanpa mencampurnya dengan urusan pribadi. Ini merupakan sebagian alasan diperlukannya sikap professional dalam diri anda masingmasing. Manajemen komunikasi berada di dalam dan diantara sistem sosial. Manajemen komunikasi meliputi P4I (Penerimaan, Pengolahan, Penyimpanan, dan Penyampaian Informasi) dalam sub-sub sistem soaial, diantaranya adalah individu, kelompok, organisasi, massa, dan masyarakat.

Satgas Aman Nusa Madago Raya II dilaksanakan untuk penanganan Covid -19 dalam rangka percepatan antisipasi dampak
Covid-19. Personel yang terlibat dalam Operasi Aman Nusa Madago Raya II dapat memberikan pemahaman kepada masyarakat luas untuk tidak melakukan kegiatan-kegiatan yang sifatnya berkumpul secara beramai-ramai atau menghindari tempat keramaian seperti yang telah dianjurkan pihak pemerintah.

Terkait pandemik Covid-19, di Kab. Sigi masih sulit untuk melaksanakan social distancing, physical distancing, stay at home, termasuk memberlakukan New Normal, sehingga masih dapat ditemukan adanya kerumunan massa tanpa memperhatikan protokol kesehatan dalam penanganan dan pencegahan Covid-19 di Kab. Sigi baik itu pada kegiatan-kegiatan ekonomi maupun kegiatan sosial kemasyarakatan yang masih memegang erat sifat kekeluargaan, sikap gotong royong serta adat istiadat yang monoton seperti yang terlihat dalam masih dilaksanakannya acara / upacara perkawinan, kelahiran maupun kematian.

Seperti yang dikatakan oleh bapak Nuim sebagai berikut :

"Melalui Gugus Tugas Percepatan

Penanganan Wabah Covid19

Tingkat Kabupaten dan Kecamatan, Satgas Ops Aman Nusa II 2020, dan operasi-operasi kepolisian selama tahun 2020, pada lokasilokasi publik seperti pasar-pasar, tempat wisata, jalan-jalan poros, baik melalui penyebaran stiker, selebaran, pamflet, dan pengeras suara. Secara umum himbauan himbauan tersebut dapat diterima oleh masyarakat dan tidak memunculkan sikap resitensi, namun masyarakat masih sulit untuk melaksanakannya terutama untuk menghindari kerumunan massa".

\section{Differentiate important information and eliminate non essential information (Membedakan informasi penting dan menghilangkan informasi yang tidak penting)}

Tahap ini bertujuan memilih-milih sedemikian rupa informasi mengenai 
pekerjaan agar pelaksana pekerjaan dapat membuat prioritas pekerjaan berdasarkan tingkatan informasinya. Tahap ini ialah tahap dimana membuat strategi yang akan diterapkan untuk menjalankan perusahaan dan menempatkan anggota organisasi yang sesuai dengan bidang pekerjaan yang dibutuhkan.

Strategi management dimaksudkan agar organisasi dapat dikendalikan dengan baik untuk mencapai tujuannya. Oleh karena itu hal yang paling dasar bagi setiap pimpinan adalah mengetahui dengan pasti arah yang sedang dituju dan arah bagian yang dipimpinnya. Dalam kegiatan Aman Nusa dalam wilayah polres sigi, pengenalan Tujuan, Sasaran dan Target Operasi menjadi hal paling terpenting dalam hal ini.

Sebagimana yang dikatakan oleh Bapak Nuim Hayat sebagai Kaur Bin Ops (KBO Sat Intelkom Polres Sigi:

"Tujuan Operasi yakni melaksanakan bantuan Personel dan peralatan kepada Dinas Kesehatan dalam rangka penanggulangan penyebaran Covid-19 di wilayah Kabupaten Sigi. Bersama BPBD, TNI, Pemerintah Daerah dan instansi terkait lainnya yang tergabung dalam Gugus Tugas Percepatan Penanganan Corona Virus Disease-2019 (Covid-19) membentuk satuan tugas yang terdiri dari beberapa cluster dalam rangka penyelamatan terhadap korban/pasien".

Ditambahkan oleh Anggota Intel Kaur Bin Ops bapak I Wayan Agus Susanto :

"Sebagai tindakan percepatan dalam rangka penanganan Corona Virus Disease-2019 (Covid-19) di seluruh wilayah Kabupaten Sigi, serta melakukan langkah-langkah tanggap darurat bencana dan pasca bencana bersama instansi terkait dalam rangka penanganan Corona Virus Disease 2019 (Covid-19). Sebagai pedoman pelaksanaan kegiatan dalam penanganan bencana penyebaran Corona Virus Disease 2019 (Covid-19), Pelibatan Polri secara aktif dalam upaya membantu penanganan bencana penyebaran Corona Virus Disease 2019 (Covid-19) di seluruh wilayah Kabupaten Sigi”.

Selaras yang dikatakan oleh Anggota Intel Kaur Bin Ops yang terlibat kegiatan yakni bapak Musrif :

"Mencegah dan meminimalisir adanya korban jiwa akibat penyebaran Corona Virus Disease 2019 (Covid-19). Bersinergi dengan instansi terkait (khususnya BPBD, TNI, Pemda dan lainnya) guna bersama-sama turun ke lapangan untuk mensosialisasikan protokol kesehatan dan memberikan himbauan dalam rangka pencegahan penyebaran Corona Virus Disease 2019 (Covid-19) di wilayah masing- masing. Pemberdayaan masyarakat dalam penanggulangan bencana pada status keadaan darurat dimulai sejak status siaga darurat, tanggap darurat dan transisi darurat ke pemulihan, Melakukan mapping wilayah rawan penyebaran Covid19 menciptakan di wilayah Kabupaten Sigi. Mendisplikan Masyarakat dalam melaksanakan protokol kesehatan Covid-19. Mengamankan dan mendukung progam percepatan dan penanganan Covid-19 serta pelaksanaan vaksinasi Covid-19 yang akan dilaksanakan pada tahun 2021".

Dari pemaparan diatas dapat kita lihat langkah yang perlu dilalui melibatkan sejumlah pihak didalam melaksanakan kegiatan tersebut yang terdiridari berbagai instansi yang ada. Dengan tujuan yaitu menyelaraskan program dan tindakan setiap komponan atau bagian menuju satu sasaran yang sama.

Analisis situasi diharapkan akan mampu memberikan gambaran yang faktual terhadap objek yang menjadi kajian. Jika 
analisis dilakukan secara akurat maka dapat mengidentifikasi peluang keberhasilan secara akurat serta peluang yang dapat diambil. Melalui hasil yang akurat akan memunculkan tindakan yang strategis sehingga memunculkan peluang keberhasilan yang cukup.

View problem-connected events, phenomena and concepts in an integrated context that makes it easier to make sense of, or explain what is occurring (Melihat peristiwa, fenomena dan konsep yang terkait dengan masalah dalam konteks terintegrasi yang membuatnya lebih mudah dipahami, atau menjelaskan).

Tahapan ini sebagai upaya untuk membuat spesifikasi pekerjaan dan mendistribusikannya kepada karyawan, sesuai dengan wewenang dan tanggung jawabnya, serta mampu mengantisipasi kemungkinan yang terjadi. Tahap ini merupakan tahap dimana instansi menjalankan strategi yang telah ditetapkan, melihat apakah peristiwa fenomena, konsep dan dijalankan sudah sesuai dengan yang direncanakan.

Upaya Pemerintah dalam menyiapkan vaksin COVID-19 terus dilakukan. Selain mempersiapkan penyediaan vaksin COVID-19 dengan melewati tahapan-tahapan pengujian klinik, hingga dikeluarkannya izin dari Badan POM, kesiapan tenaga kesehatan juga dilakukan. Sebanyak 440.000 tenaga kesehatan dan 23.000 vaksinator terus mempersiapkan diri untuk pelaksanaan vaksinasi hingga ke seluruh daerah. Sampai dengan 5 Desember 2020, sudah dilakukan pelatihan sebanyak 12.408 orang untuk 21 provinsi. Sementara workshop penyiapan bagi tenaga vaksinator juga telah dilangsungkan untuk 29.635 orang dari 34 provinsi termasuk Sulawesi Tengah.

Pada aspek sosial kemasyarakatan warga Kab. Sigi masih memegang erat sifat kekeluargaan, sikap gotong royong serta adat istiadat seperti acara / upacara perkawinan, kelahiran maupun kematian, sehingga meski di masa pandemic Covid-19, di Kab. Sigi tetap sulit untuk melaksanakan social distancing, physical distancing, stay at home, meski sesekali disediakan sarana / prasarana dalam rangka memenuhi standar New Normal. Seperti yang dikatakan oleh bapak Nuim :

"Terkait pandemic Covid-19, di Kab. Sigi masih sulit untuk melaksanakan social distancing, physical distancing, stay at home, termasuk memberlakukan New Normal, sehingga masih dapat ditemukan adanya kerumunan massa tanpa memperhatikan protokol kesehatan dalam penanganan dan pencegahan Covid19 di Kab. Sigi baik itu pada kegiatan-kegiatan ekonomi maupun kegiatan sosial kemasyarakatan yang masih memegang erat sifat kekeluargaan, sikap gotong royong serta adat istiadat yang monoton seperti yang terlihat dalam masih dilaksanakannya acara / upacara perkawinan, kelahiran maupun kematian".

Banyak hal yang menjadi tantangan ataupun hambatan dalam pelaksanaan kegiatan Aman Nusa II yang dilaksnakan oleh Polres Sigi itu sendiri. Dimana hambatan-hambatan yang muncul menjadi halangan yang sangat mendasar bagi keberlangsungan maupun keefektivitas dari kegiatan tersebut.

Seperti yang dikatakan oleh bapak Anggota Intel Kaur Bin Ops Musrif:

"Pemerintah daerah kekurangan anggaran dan terjadinya defisit dalam jumlah besar dalam menaggulangi Covid-19 sehingga kegiatan dan program pemerintahan terganggu, ditambah lagi Kelangkaan dan melonjaknya harga-harga bahan pokok maupun bahan makanan lainnya, harga masker dan hand zanitiser serta adanya spekulasi para pedagang dan distributor untuk menaikan harga". 
Kutipan wawancara diatas mempertegas bahwa Pemerintah telah melakukan berbagai upaya dalam penanganan dan terus menekan penyebaran Covid-19, manum pada kenyataannya kegiatan yang dilakukan tidaklah selalu mulus dalam pelaksanaannya. Ada berbagai macam kendala yang ditemui dan dirasakan langsung oleh pihak terkait.

Formulate strategy that can serve as the basic for plans and their implementations (Merumuskan strategi yang dapat berfungsi sebagai dasar untuk rencana dan implementasinya)

Merupakan tahapan yang sangat menentukan

keberhasilan

organisasi/perusahaan dalam mencapai tujuan. Rumusan strategi yang tepat dan mudah diimplementasikan akan menciptakan suasana kerja yang kondusif dan mendorong terciptanya kinerja yang memuaskan. Tahap ini merupakan tahap dimana instansi melakukan pengawasan. Apakah konsep strategi yang direncanakan sudah terimplementasikan dengan baik demi tercapainya tujuan yang ingin dicapai.

Dalam proses komunikasi, komunikator memegang peran penting terhadap keberhasilan komunikasi. Ada faktor penting dari komunikator ketika menyampaikan pesan kepada khalayak sasaran, yakni terkait daya tarik sumber (source attractiveness) dan kredibilitas sumber (source credibility). Agar pesan benar-benar dapat diterima oleh khalayak sasaran, komunikator harus memiliki kredibilitas. Kredibilitas di sini mengandung 2 (dua) unsur, yaitu: pertama adalah keahlian atau expertise. Artinya, komunikator harus memiliki keahlian atau kecakapan yang diakui oleh khalayak sasaran. Unsur kedua adalah dapat dipercaya atau trustworthiness. Sumber penyampai pesan harus dapat membangun kepercayaan pada khalayak sasaran. Nuim :
Seperti yang dikatakan oleh bapak
"Mempersiapkan dan menyusun data awal operasi, Mempersiapkan piranti lunak, piranti keras organisasi operasi, administrasi operasi serta gelar operasi, Melaksanakan rapat koordinasi dengan TNI, BPBD, Pemda, instansi terkait lainnya serta fungsi Opsnal dan Kewilayahan dalam rangka menyamakan persepsi dan pemahaman dalam pelaksanaan operasi, Penyiapan personel, logistik, materiil, dukungan anggaran dan penggelaran jaringan komunikasi yang diperlukan untuk mendukung pelaksanaan kegiatan operasi, Membentuk Satuan Tugas Operasi Resor ( Satgasres ) terdiri dari Satgas-1 Deteksi, Satgas-2 Pencegahan, Satgas-3 Penanganan, Satgas-4 Pengawalan dan Pengamanan, Satgas-5 Gakkum, dan Satgas-6 Banops,Memberikan arahan kepada Pesonel yang terlibat Operasi mengenai sasaran dan cara bertindak yang harus dilakukan.

Perumusan strategi yang akan dilakukan, Sudah termasuk di dalamnya adalah pengembangan tujuan, mengenai peluang dan ancaman eksternal. Menetapkan kekuatan dan kelemahan secara internal, menetapkan suatu objektivitas, mengahasilkan strategi dan memilih strategi untuk dilaksanakan.

Implementasi strategi Setelah meumuskan dan memilih strategi yang telah ditetapkan, maka langkah berikutnya melaksanankan strategi yang ditetapkan tersebut. Dalam tahap pelaksanaanya strategi yang telah dipilih sangat membutuhkan komitmen dan kerja sama dalam pelaksanaan strategi, jika tidak maka proses formulasi dan analisis strategi hanya akan menjadi impian yang jauh dari kenyataan. Implementasi strategi bertumpu pada alokasi dan pengorganisasian sumber daya yang ditempatkan melalui penetapan struktur organisasi dan mekanisme 
kepemimpinan yang dijalankan bersama budaya perusahaan dan organisasi.

Proses pelaksanaan peembentukan Satuan Tugas Operasi Resor ( Satgasres ) Sigi memiliki TUPOKSI masing-masing. Dimana tugas pokok dan fungsi tiap bagian memiliki kerja masing-masing. Berikut pemaparan setiap Satgas yang terlibat, seperti yang dijelaskan oleh bapak Nuim :

"Satgas 3 Penanganan, Dipimpin oleh Kasat Binmas, dengan tugas, 1 . Bersama dengan instansi kesehatan lainnya memberikan pelayanan kesehatan kepada masyarakat korban Covid-19,2. Melakukan sterilisasi dengan penyemprotan disinfektan pada lokasi terjadinya wabah Covid-19, 3 . Melaksanakan pengukuran suhu tubuh dengan menggunakan termos scanner dan melakukan penyemperotan disinfektan ke seluruh ruangan perkantoran di lingkungan Polri, komplek Polri, 4.Pemberian vitamin kepada Personel Polri/petugas Operasi Aman Nusa II Covid-19, 5. Pemberian masker kepada seluruh Personel Polri, 6. Melaksanakan kegiatan pemeriksaan/deteksi Covid19 dan pelacakan (tracking) bagi anggota Polri dan keluarganya yang mengalami /diduga terpapar Covid-19"

\section{Analisis dan Interpretasi}

Keberhasilan sebuah program akan sangat ditentukan oleh bagaimana sebuah organisasi mengatur dan mengelola seluruh tahapan dalam program tersebut. Dimulai dari bagaimana membuat perencanaan yang matang, bagaimana mengoptimalkan penggunaan sumberdaya yang efisien dan sesuai kebutuhan, serta berbagai macam hal teknis lainnya yang nantinya kan mendukung keberhasilan program tersebut.

Dalam ranah manajemen komunikasi, pada dasarnya tidak dapat dilepaskan dari apa itu perencanaan komunikasi. Keduanya adalah hal yang saling berkaitan satu sama lain. Sebagaimana empat garis besar tahapan implementasi manajemen komunikasi GR Terry yang ada dalam penelitian ini, tahapan-tahapan tersebut masih membutuhkan penjabaran yang lebih spesifik terkait bagaimana mengelola proses komunikasi khususnya dalam pelaksanaan operasi aman nusa madago raya II ini. Tahapan-tahapan implementasi tersebut diantaranya perlu kembali dijabarkan dalam aspek perencanaan, pengorganisasian, penggerakan, dan pengawasan.

Aspek pertama yaitu perencanaan. Perencanaan sebagai dasar pemikiran dari tujuan dan penyusunan langkah-langkah yang akan dipakai untuk mencapai tujuan. Merencanakan berarti mempersiapkan segala kebutuhan, memperhitungkan matang-matang apa saja yang menjadi kendala, dan merumuskan bentuk pelaksanaan kegiatan yang bermaksud untuk mencapai tujuan. Perencanaan dalam definisi lainnya diartikan sebagai segala sesuatu yang harus dilakukan, diupayakan secara sistematis, dan dinyatakan secara tertulis. Dalam konteks operasi aman nusa madago raya ini, meskipun perencanaan secara umum bersifat instruksional terstruktur dari pusat namun Polres Sigi perlu membuat perencanaan yang skalanya lebih kecil. Perencanaan yang didasari oleh situasi dan kondisi yang terjadi di wilayah Kabupaten Sigi. Menghadapi situasi krisis Covid -19 , setiap daerah tentunya memiliki respon yang berbeda sehingga penanganan yang dilakukan seharusnya dapat disesuaikan dengan hal tersebut dan tidak digeneralisir. Kendala yang muncul pun tidak serta merta sama dengan yang terjadi di daerah lain, meskipun dalam konteks Covid-19 dari beberapa permasalahan 
nampak tidak jauh berbeda. Namun, respons terhadap kendala ini harus dapat dijadikan bahan pertimbangan untuk membuat perencanaan agar tujuan dan capaian perencanaan dapat disusun lebih terarah. Pertimbangan-pertimbangan dasar yang dijadikan acuan dalam sebuah perencanaan awal, memungkinkan tujuan program dapat tercapai dengan baik.

Aspek kedua berkaitan dengan pengorganisasian yaitu sebagai cara untuk mengumpulkan orang-orang dan menempatkan mereka menurut kemampuan dan keahliannya dalam pekerjaan yang sudah direncanakan. Hal ini sangat erat hubungannya dengan pemilihan sumber daya. Sumber daya bukan hanya berbicara sumber daya manusia, melainkan hal-hal lain yang bersifat non manusia. Dalam program operasi aman nusa madago raya II ini, personil Polres Sigi termasuk salah satu unsur sumberdaya inti dan masih melibatkan personil terkait lainnya. Pengorganisasian diperlukan agak sumber daya yang digunakan berkesesuaian dengan tugas pokok fungsi yang dikerjakan, dimana setiap yang terlibat bekerja sesuai dengan apa yang menjadi keahlian dan bidangnya. Program operasi ini, terlihat telah begitu baik melakukan pengorganisasian sumber daya. Dimana setiap bagian program dijalankan oleh mereka yang memiliki kompetensi sesuai dengan apa yang ditugaskan. Pengorganisasian yang baik memungkin program dapat dijalankan dengan baik dan minim resiko akan tumpang tindih tugas.

$$
\text { Berikutnya adalah aspek }
$$
penggerakan (Actualing), yaitu untuk menggerakan organisasi agar berjalan sesuai dengan pembagian kerja masing-masing serta menggerakan seluruh sumber daya yang ada dalam organisasi agar pekerjaan atau kegiatan yang dilakukan bisa berjalan sesuai rencana dan bisa mencapai tujuan. Aspek ini merupakan aspek yang berkaitan langsung dengan proses implementasi program. Segala upaya yang sedang dijalankan dalam program operasi aman
Nusa II Madago Raya Polres Sigi digerakan sebagaimana tugas dan fungsinya masingmasing. Aspek terakhir yaitu aspek pengawasan atau controlling. Diperlukan guna memastikan seluruh yang terlibat dalam program sedang berkerja dengan sesuai dengan tugas dan fungsi masingmasing. Pengawasan yang tepat akan dapat mencegah terjadinya kesalahan dalam implementasi program yang sedang dijalankan.

\section{Simpulan}

Penanganan Covid-19 di wilayah Kabupaten Sigi juga ikut melibatkan seluruh unsur pemerintah, baik TNI POLRI maupun stakeholder lainnya. Melalui Gugus Tugas Percepatan Penanganan Wabah Covid-19 Tingkat Kabupaten dan Kecamatan, Satgas Operasi Aman Nusa II Madago Raya di wilayah Kabupaten Sigi terbilang berjalan baik dengan mengerahkan seluruh komponen sumberdaya sesuai dengan tugas pokok dan fungsi masing-masing. Berbagai upaya yang diantaranya telah dilakukan yakni imbauan di berbagai titik publik, pemanfaatan media komunikasi secara menyeluruh, diperkuat dengan koordinasi yang baik antar unsur yang terlibat.

$$
\text { Implementasi manajemen }
$$

komunikasi dalam operasi aman nusa II Madago Raya di wilayah Kabupaten Sigi ini pun telah melalui empat tahapan. Pertama yakni dengan merumuskan strategi yang dapat berfungsi sebagai dasar untuk rencana dan implementasinya, kemudian tahapan membedakan informasi penting dan menghilangkan informasi yang tidak penting,tahapan ketiga yakni melihat peristiwa, fenomena dan konsep yang terkait dengan masalah dalam konteks terintegrasi yang membuatnya lebih mudah dipahami, dan yang keempat adalah tahapan yang bertujuan merumuskan strategi yang dapat berfungsi sebagai dasar untuk rencana dan implementasinya. 


\section{Referensi}

Aw, Suranto. 2011. Komunikasi Interpersonal. Yogyakarta : Graha Ilmu.

Cangara, Hafied. 2011. Pengantar Ilmu Komunikasi. Jakarta : PT. Rajagrafindo Persada.

Devito, Joseph A. 1997. Human Communications. Jakarta : Professional Books.

Effendy, Onong Uchjana. 1984. Ilmu Komunikasi, Teori dan Praktek. Bandung : PT. Remaja Rosdakarya.

Effendy, Onong Uchjana. 1986. Dinamika Komunikasi. Bandung: PT. Remaja Rosdakarya.

Effendy, Onong Uchjana. 2003. Ilmu, teori dan filsafat komunikasi. Bandung: PT. Citra Aditya Bakti.

Fathoni, H. Abdurrahmat. 2006. Organisasi dan Manajemen Sumber Daya Manusia. Jakarta:Rineka Cipta.

Gomes, F. Cardoso. 1995. Manajemen Sumber Daya Manusia. Yogyakarta : C.V Andi Offset.

Handoko, Hani. T. 2000. Manajemen Personalia dan Sumber Daya Manusia. Yogyakarta : BPFE

Hardiyansyah, 2012. Sistem Administrasi Dan Manajemen Sumber Daya Manusia Sektor Publik Dalam Perspektif Otonomi Daerah. Yogyakarta : Gava Media.

Hasibuan, Malayu. 2002. Manajemen Dasar, Pengertian, dan Masalah. Jakarta: PT. Bumi Aksara.

Hasibuan, Malayu. 2006. Manajemen Sumber Daya Manusia. Jakarta: PT. Bumi Aksara.

Kriyantono, Rakhmat. 2007. Teknis Praktis Riset Komunikasi. Jakarta : kencana Prenada Media Group.

Lister, M., Dovey, J., Giddings, S., Kelly, K., \& Grant, I. 2009. New Media: a critical introduction (Second Edition.). New York,: Routledge.
Mcluhan, M. 1964. Understanding Media: The extensions of man (First Edit.). London, New York: McGraw Hill.

Moekijat, 1999. Manajemen Sumber Daya Manusia. Bandung: Mandar Maju.

Mulyana, Deddy. 2005. Komunikasi Efektif. Bandung: PT. Remaja Rosdakarya.

Mulyana, Deddy. 2010. Ilmu Komunikasi Suatu Pengantar. Bandung : PT. Remaja Rosdakarya

Yodmani, S., \& Hollister, D. 2001. Disasters and Communication Technology: Perspectives from Asia. Second Tampere Conference on Disaster Communications (pp. 28-30) 